\section{Fundamental Indexation in Brazil: a competitive strategy?}

\author{
Raphael Moses Roquete ${ }^{1}$ \\ Ricardo Pereira Câmara Leal ${ }^{1}$ \\ Carlos Heitor Campani ${ }^{1}$ \\ ${ }^{1}$ Federal University of Rio de Janeiro, The Coppead \\ Graduate School of Business, Rio de Janeiro, Brazil
}

\section{Abstract}

Purpose - This article analyzes fundamental indexation in Brazil relative to the $\mathrm{IBrX} 100$ and selected stock funds in the period between June 2003 and May 2015. This strategy relies on weights based on fundamental indicators and not on market prices.

Design/methodology/approach - Fundamental indices built with the IBrX 100 stocks were weighted according to fundamental indicators. The fundamental weighting method sets the weight of each stock as proportional to a previously determined fundament value. This article also considers an ordinal weighting.

Findings - The results indicate that fundamental indices do not display positive and statistically significant returns and alphas after adjusting a five risk factor model and transaction costs. The ordinal weighting suggests that fundamental indicator outliers do not drive results. The evidence also suggests that fundamental indices might perform better in bear markets.

Originality/value - In general, fundamental indices behave like value stocks and do not present abnormal returns. This is consistent with the absence of fundamental index products in the Brazilian market.

Keywords - active portfolio management, passive portfolio management, fundamental indexation, stock funds.
Received on

12/05/2016

Approved on

$14 / 03 / 2018$

\section{Responsible editor:}

Prof. Dr. Eduardo Contani

Prof. Dr. João Maurício Gama

Boaventura

\section{Evaluation process:}

Double Blind Review

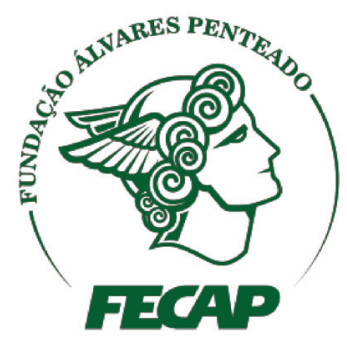

Review of Business Management 


\section{Introduction}

Portfolios weighted by the market value of stocks will not necessarily lead to an efficient relationship between risk and return. Haugen and Baker (1991), for example, showed that there are alternatives that lead to the same expected returns, but with lower volatility. Markowitz (2005) argues that even if the restrictions of long and short positions in the real world were taken into account, the market portfolio, often represented by a stock index weighted by market value, will not be efficient. Passive management usually seeks to imitate one of these indices.

Alternatives for building and weighting passive portfolios, therefore, have been offered. Arnott, Hsu, and Moore (2005) proposed portfolios weighted according to the fundamental indicators of companies and not on the basis of market prices. They claim that the traditional weighting by market value method is sub-optimal because prices may introduce noise and not fully reflect the fundamentals of the companies. The form of weighting proposed by these authors considers that the weight of each stock will be its proportion in the total value of the fundamental indicator selected. Assuming, for example, that the fundamental indicator selected is the company's revenue, whose amount is $\mathrm{R} \$ 10$ million, and the sum of the revenue of the companies being considered is $\mathrm{R} \$ 100$ million, the weight of this asset in the fundamental index (or portfolio) would be 10 percent in the period.

The objective of this article is to apply the fundamental indexation of Arnott et al. (2005) to the Brazilian market and check whether it leads to an excess return in relation to indexation by market value, between June 2003 and May 2015. The article is the first to address fundamental indexation exclusively in Brazil. It examines whether fundamental indexation generates abnormal risk-adjusted returns according to the Capital Asset Pricing Model (CAPM) and a fivefactor model, which is an extension from Fama and French (1993). The article also contributes to extending the method proposed by Arnott et al. (2005) and employs an alternative weighting of the fundamental indices to mitigate the effects of extreme values on the weights. Finally, a contrast is made between the fundamental indices and actively managed stock mutual funds considering their behavior in periods of market highs and lows.

Fundamental indexation may be relevant to the investment fund industry in Brazil, which has been growing substantially. The Brazilian Association Financial and Capital Markets Entities (ANBIMA) (2016) reported that the assets under management (AUM) of investment funds for the 12 months before February 2016 exceeded R\$ 3 trillion in contrast with $\mathrm{R} \$ 400$ billion in 1996. Despite this, indexed (passive) stock funds represent a much smaller portion of the total AUM of stock funds than those of actively managed stock funds. Data from February 2016 from ANBIMA showed that less than two percent of the AUM of stock funds was made up of indexed stock funds. On the other hand, according to the Investment Company Institute (ICI) (2016), indexed stock funds in the US continue to grow and accounted for about 22 percent of the mutual fund industry there in 2015. It was not possible to identify Brazilian indexed stock funds that adopt fundamental indexation, but stock funds that consider this type of weighting may be interesting products.

The theme of fundamental indexation in Brazil is also relevant because of the difficulty for managers to achieve a better yield than that of the yields from Interfinancial Certificates of Deposit (CDI) (Dana, 2015). Since the beginning of the Real Plan (July 1994) until May 2015, CDI performance was 3,626.15 percent in comparison with 2,269.94 percent for the main stock index in Brazil, the Ibovespa. Some international financial crises that occurred in the period also contributed to increasing the difficulty of stocks outperforming the fixed income market in Brazil.

The results reported here show that only the portfolio built according to the fundamental 
index based on free cash flow showed superior performance to the index weighted by market value ( $\mathrm{IBrX} 100)$, and even then, only when the CAPM alpha is considered. When a five-factor model is considered, this result disappears, corroborating with international authors that claim that results favorable to fundamental indices are nothing more than evidence of a value stock premium. This article continues with a review of the literature, followed by details of the sample and methodology, a discussion of the results, and the conclusions.

\section{Literature Review}

\section{I Initial evidence in the US}

Arnott et al. (2005), Treynor (2005), Hsu (2006), Hsu and Campollo (2006), and Arnott and Hsu (2008) reported that market value weighting might lead to sub-optimization of the risk-return ratio of a portfolio because stock prices are very volatile in relation to their fundamentals. Siegel (2015) argued that stock prices are susceptible to trades that are not related to the fundamental values of companies, but result from the activity of traders related to "liquidity" or "noise", who buy and sell shares influenced by tax reasons, to rebalance portfolios, or for other personal reasons and, therefore, are not necessarily the best estimate of the value of firms. The author called this condition the Noisy Market Hypothesis (NMH).

Arnott et al. (2005) proposed fundamental indexation whose selection, weighting, and rebalancing disregard the market value weighting. This strategy sets out that the weight of each asset in a portfolio is determined according to some fundamental index of the company, such as sales, dividends, cash flow, and earnings, among others. The objective of the authors was to deviate from weighting according to market prices, maintaining, however, the positive attributes of market value passive indexation, such as a low turnover when rebalancing the portfolios once a year, and liquidity, even though admittedly lower
(Arnott, Hsu, \& Moore, 2005; Arnott \& West, 2006; Hsu \& Campollo, 2006).

Arnott et al. (2005) argued that portfolios built according to fundamental indicators tend to have higher returns and less volatility than those weighted according to market value. These portfolios, represented by fundamental indices, would maintain the main benefits of a passive strategy, such as exposure to companies of higher market value, concentration in stocks with good liquidity (which reduces transaction costs), betas similar or lower than those of the indices weighted by market value, and a high correlation with the market. The authors built fundamental indices for the US stock market based on revenue, shareholders' equity, gross sales, dividends, cash flow, and number of employees, in addition to building an equally weighted aggregate index with all these measures except for gross revenues and the company's number of employees. The rebalancing of the portfolio occurred once a year. On average, the portfolios built outperformed the S\&P 500 by $1.97 \%$ per year, with the same volatility for the period between 1964 and 2002 .

Also in the US, Chen, Chen, and Basset (2007) estimated the fundamental weights of assets by means of a median of weights according to the historical market values of 1000 companies between 1962 and 2003, without employing their accounting information, such as in Arnott et al. (2005). The authors argue that this information changes slowly and that prices always converge to the fair price in accordance with the fundamentals. The results indicated the superiority of fundamental indexation. Amenc, Goltz, Lodh, and Martellini (2012) calculated the excess return from minimum variance portfolios, of the maximum Sharpe ratio, equally weighted portfolios, and ones based on fundamental indexation, in relation to the S\&P 500 between 2003 and 2011. They showed that all these strategies were winners at some time, but it was not possible to argue that fundamental indexation is better. 


\subsection{Studies in other countries}

Fundamental indexation has also been tested in other countries. Estrada (2008) mixed fundamental indexation with international diversification through a global fundamental index of dividends considering 16 markets that represented just over 90 percent of world market capitalization. The author compared it to an index based on the market value for the period between 1974 and 2005 and found an excess return at an average annual rate of $1.9 \%$ and a better returnto-risk ratio in favor of fundamental indexation. Hsu and Campollo (2006) created fundamental indices for 23 developed countries and a global one for the period from 1984 to 2004, finding superior results for the average of the fundamental indices of $2.8 \%$ p.a. and for the global one of $3.5 \%$ p.a. in relation to the corresponding indices computed by Morgan Stanley Capital International (MSCI), which are weighted by market value.

Walkshäusl and Lobe (2010) created a global fundamental index considering 50 countries, of which 22 were emerging and 28 developed, and fundamental indices for each country in the period from 1982 to 2008 . The aggregate index of each country was formed by the same allocations in four individual fundamental indices calculated with the value of shareholders' equity, cash flow, dividends, and sales. The authors found superior performance for the global fundamental index and for the fundamental indices of each country in relation to the index based on market value. However, this result was less prominent for the indices of each country after carrying out the Ledoit and Wolf (2008) bootstrapping procedure in the robustness tests. The authors found more positive results for fundamental indexation in developed countries than in emerging ones. This evidence was contrary to expected because the likelihood of prices not converging to the fundamentals would be greater in emerging markets, where volatility also tends to be higher. Brazil was part of the authors' sample beginning in 1999 and with 88 shares. The monthly results of the Brazilian aggregate index showed a difference of return in relation to the index weighted by market capitalization of only $0.31 \%$ p.a., with no statistical significance for the difference between the Sharpe ratios.

Hemminki and Puttonen (2008) examined the benefits of fundamental indexation in the euro zone. The 50 companies with the best fundamentals were selected every year based on the DJ Euro Stoxx Total Market Index, which represented approximately 95 percent of the value of the free floating shares of the twelve countries in the euro zone at the time. The authors built five portfolios indexed according to the fundamentals and an additional one equally weighted by each one of them and they found results consistent with those of Arnott et al. (2005) for the period from 1996 to 2006, but with less significance. The authors mention the shorter period as a possible explanation for this fact.

Finally, Mar, Bird, Casavecchia, and Yeung (2009) studied fundamental indexation in Australia in the period from 1995 to 2006 by means of four fundamental indices and one composite index aggregating these four. The aggregate index outperformed the index weighted by market value by $1.93 \%$ p.a., but had a lower performance in 1997 and 1998 during the Internet bubble. Basu and Forbes (2014) also analyzed the Australian stock market for the period between April 1985 and March 2010. The returns of the fundamental indices were all higher in relation to the market value weighted index with a similar or lower volatility. The aggregate fundamental index, for example, outperformed the market value weighted one by $3.5 \%$ p.a., with lower volatility.

\section{$2 \cdot 3$ Criticism of fundamental indexation}

The main criticisms relate to higher transaction costs due to the lower liquidity and higher turnover of the portfolio, the subjective choices of the fundamentals considered for the selection and weighting of assets, and it being a disguised form of a value stock strategy or 
an active strategy claiming to be passive (Blitz \& Swinkels, 2008; Ferri, 2014). Perold (2007) criticizes the assertion that indices weighted by market value will present inferior results relative to those of fundamental indices without the investor knowing the fair price of stocks. According to the author, the NMH reports that the investor is not sure about the fair price and only knows the market value; however, the proponents of fundamental indexation implicitly consider that the investor knows the fair value of the assets and, therefore, conclude that indices weighted by the market value lead to lower performance. Perold (2007) and Graham (2012) say that, disregarding the knowledge of fair value and if the error is random, there is no way to know whether a stock is overvalued or not. Portfolios weighted by market value, therefore, would not necessarily be inferior to those weighted by means of fundamental indices. According to Kaplan (2008), the advocates of fundamental indexation affirm that the weights of assets based on fundamentals are not biased estimators of the weights, considering the fair value of each asset, and that the errors are statistically independent of the market value. However, according to the author, this argument is inconsistent since the sources of errors and uncertainties are also determinants of the market value. Finally, Blitz and Swinkels (2008) argue that quantitative strategies to optimize the return-to-risk ratio can outperform fundamental indices.

\section{Sample and Methodology}

\section{I Stock and stock fund samples}

The sample for this article is made up of the companies present in the IBrX 100 in June of each year and the analysis period was from June 2003 to May 2015 (12 years or 144 months). The IBrX 100 was the index selected because it is weighted by the market value of the free floating shares (BM\&FBovespa, 2015a). This type of index is the main object of criticism of Arnott et al. (2005), in addition to containing more shares than the Ibovespa. Furthermore, it should be noted that the Ibovespa was weighted according to the market liquidity of the stocks up to December 2013, when limits were introduced to prevent certain companies from being included or having a weight greater than 20 percent of the index or twice the weight that they would have with the former weighting criterion. At this point the weighting began to be calculated by the free floating shares' market value, subject to these limits, which do not exist in the IBrX 100 (BM\&FBovespa, 2015b). Thus, the Ibovespa does not fully correspond to market value indexation. Despite these differences, the correlation between the monthly returns of the Ibovespa and $\mathrm{IBrX}$ 100 was 97 percent in the sample period. Finally, it is worth noting that the prices collected for the stocks were those adjusted to cash and stock dividends, rights offers, etc. in the Economatica database.

The year 2003 was chosen as the beginning of the sample because it represents the beginning of a period of significant increases in trading volume in the stock exchange, which may imply less distortion in stock prices due to liquidity problems. According to Mendonça, Galvão, and Loures (2011), there was an increase of 1,253\% in the trading volume of the Ibovespa in the first seven years of President Lula's government. The year 2003 also marked the beginning of a downward trajectory of country risk, resulting in a greater inflow of foreign capital and an increase in the number of contracts traded on the futures market, suggesting more market development.

In addition to the comparison with the IBrX 100, the paper compares portfolios built according to the fundamental indicators, the fundamental indices, with actively managed Brazilian stock funds. On August 19, 2015 , the following criteria were adopted to select the stock funds in the Quantum/Axis system based on the ANBIMA criteria: (i) classification as "IBOVESPA Active Shares" and "IBrX 100 Active Shares"; (ii) available to investors in general, i.e., not exclusive funds or intended only for qualified 
investors; (iii) stock fund inception prior to June 2003; and (iv) in operation until May 2015. These filters selected 42 stock funds, the list of which has been omitted due to limited space, but is available from the authors.

\subsection{Calculation of the fundamental indices}

The methodology of this article derives from Arnott et al. (2005) and Basu and Forbes (2014). Fundamental portfolios or indices were calculated based on fundamental indicators employed by these authors: net revenue, shareholders' equity, dividends, operating cash flow, and net cash flow. The number of employees and net payout (dividends added to stock repurchases and subtracted from the cash received from issues) used by Arnott et al. (2005) were not considered because of insufficient data. All fundamental indicator amounts were obtained from the Bloomberg system for December 31 of each year and were measured in Brazilian reais. The Appendix presents the definition of each one of them as well as their code in the Bloomberg database for the purposes of replicating the procedure.

The fundamental indices with the stocks in the IBrX 100 were formed at the end of June of each year of the sample. This month was chosen because at this time of the year companies have already disclosed their financial statements for the previous year required for obtaining the fundamental indicators and weighting. If a company had more than one kind of stock (common and preferred), only the most liquid one was included in the fundamental index.

The weight of the stocks in each fundamental index was determined using the same method as in Arnott et al. (2005), depicted in Equation 1, where $w_{k, i}$ is the weight of each stock $i$ in the fundamental index calculated for the fundamental indicator $k$, and $F_{k^{2}}$ is the value of the fundamental indicator $k$ for stock i. $N$ is the total number of stocks included in the fundamental index. This calculation was carried out for each year, but the time subscript was omitted in Equation 1. A value of zero was assigned to the negative fundamental indicators.

$\mathrm{W}_{\mathrm{k}, \mathrm{i}}=\frac{\max \left(0, F_{k, i}\right)}{\sum_{i=1}^{N} \max \left(0, F_{k, i}\right)}$

An alternative weighting aims to verify the effect of extreme and negative values of the fundamental indicators on the weights calculated with Equation 1. The stocks were sorted in ascending order according to each fundamental indicator, assigning the rank of 1 to the smallest fundamental indicator. In this case, the negative amounts of the fundamental indicators were kept instead of being equaled to zero. The stock with the lowest revenue was assigned the value 1 , for example. The weight of each stock was calculated as its rank number divided by the sum of the ranks of all shares from 1 up to the highest, as depicted in Equation 2, where $o w_{k, i}$ is the ordinal weight of each stock, and $O_{k, i}$ is the rank or ordinal of stock $i$ according to fundamental indicator $k$.

$$
\mathrm{oW}_{\mathrm{k}, \mathrm{i}}=\frac{O_{k, i}}{\sum_{i=1}^{N} O_{k, i}}
$$

The rebalancing took place once a year and was done in the month of June of each year using the amounts of the fundamental indicators at the end of the previous year. A new portfolio (fundamental index) was formed considering the shares included in the IBrX 100 for that month. Thus, shares that left the $\mathrm{IBrX} 100$ were not included while those that became a part of the IBrX 100 were.

\section{$3 \cdot 3$ Calculation of returns and models}

The monthly returns of the fundamental indices were estimated based on the monthly returns of each stock included in the portfolio and the weight assigned to it either by Equation 1 or by Equation 2. The initial value of each fundamental index was set at 100 points. The initial value of each stock $i$ in the fundamental index $k$ is equal 
to $w_{k, i} \times 100$. Next, the theoretical quantity $Q_{k, i}$ $=\left(w_{k, i} \times 100\right) / P_{i, 1}$ was determined, which is the division of the initial value (in points) of each stock by its closing price on the day prior to building the fundamental index. This theoretical quantity remains constant during the sample year between the beginning of June and the end of May of the following year. At the end of each month $t$ of the sample year, the closing price of each stock $i$ of the fundamental index $k\left(P_{k, i, t}\right)$ on this day was multiplied by $Q_{k, i}$. The sum of these products leads to the fundamental index value for the end of month $t\left(V_{k, t}\right)$. Equation 3 shows the calculation of this amount. The monthly return of the fundamental index $k$ is $R_{k, t}=V_{k, t} / V_{k, t-1}-1$. At the beginning of June of the following year the procedure for calculating the new weights and theoretical quantities is repeated, as well as the process of calculating the end-of-month amounts of the fundamental index.

$$
V_{k, t}=\sum_{i=1}^{N} P_{k, i, t} \times Q_{k, i}
$$

Furthermore, to present the results, the annualized geometric average of the returns was calculated as in Equation 4, using the 144 months of the sample period and the annualized volatility (standard deviation) according to Equation 5, where is the arithmetic average of the 144 monthly returns of each index. The Sharpe ratio (SR) was calculated according to Equation 6 , where is the arithmetic average of the 144 monthly CDI rates. The CDI was chosen because it is the standard benchmark for the opportunity cost of investors and is often included in the monthly performance reports of investment funds in the country, in addition to behaving in a very similar way to the rate for government securities (SELIC). The CDI rate is also subject to less government control, bearing in mind that there are targets for the SELIC rate depending on the economic policy in vogue. Furthermore, Sharpe (1994) states that the return of any asset or portfolio can be used for calculating the excess return in the numerator of the SR.

$$
\begin{aligned}
\overline{R G}_{k} & =\prod_{t=1}^{144}\left(1+R_{k, t}\right)^{12 / 144} \\
V o l_{k} & =\sqrt{12 \times\left[\frac{1}{N-1} \sum_{t=1}^{144}\left(R_{k, t}-\bar{R}_{k}\right)^{2}\right]} \\
I S_{k} & =\frac{\bar{R}_{k}-\overline{C D I}}{\frac{1}{143} \sum_{t=1}^{144}\left(R_{k, t}-\bar{R}_{k}\right)^{2}}
\end{aligned}
$$

The Jensen's alpha (1968) indicates if the fundamental indexation offers abnormal returns, considering the market risk to which the portfolio is exposed. It was estimated according to the author's original proposal (Equation 7) and also with the three-factor model from Fama and French (1993), extended with two additional factors proposed by Carhart (1997) and Keene and Peterson (2007), respectively, and tested in Brazil by Machado and Medeiros (2011) (Equation 8). In Equation 7, $R_{k, t}$ is the return in month $t$ of the fundamental index analyzed, $C D I_{t}$ is the monthly return of the CDI, and $R_{M, t}$ is the monthly return of the $\mathrm{IBrX} 100$.

$R_{k, t}-C D I_{t}=\alpha_{p}+\beta_{p}\left(R_{M, t}-C D I_{t}\right)+\epsilon_{k, t}$

The values of the additional factors of Equation 8 were obtained from the Brazilian Center of Research in Finance of the Department of Economics of the University of Sáo Paulo, which calculates them based on selected Brazilian stocks and whose website describes in detail the methodology for obtaining each factor (www. nefin.com.br).

Briefly, the portfolios that represent the four additional factors to the CAPM are estimated annually. The small-minus-big (SMB) factor results from the sorting and division of all selected stocks into three groups according to their market value at the end of December of the previous year. The SMB monthly returns are the differences between the monthly returns of the equally weighted portfolio of stocks from the small (S) 
and big (B) market value groups, excluding the middle group. Similarly, the eligible stocks are sorted and divided into three groups according to the ratio between their book and market values (book-to-market ratio) from June of the previous year in January of each year in order to calculate the high-minus-low (HML) factor. The HML monthly returns are the differences between the monthly returns of the equally weighted portfolio of stocks from the high $(\mathrm{H})$ and low (L) bookto-market groups. The winners-minus-losers (WML) factor is estimated in each month $t$ by sorting and dividing the sampled stocks into three groups according to the return accumulated between months $t-12$ and $t-2$. The WML monthly returns are the differences between the monthly returns of the equally weighted portfolio of stocks from the group of highest (W) and lowest (L) past return. Finally, the illiquid-minus-liquid (IML) factor is calculated monthly by sorting and dividing the eligible stocks into three groups according to the 12-month moving average of a measure of illiquidity. The IML monthly return is the difference between the return of the equally weighted portfolio of the less liquid shares (I) and that of the most liquid shares (L). More details about the factors can be found on the aforementioned website (www.nefin.com.br).

$$
\begin{aligned}
R_{k, t}-C D I_{t}=\alpha_{k}+\beta_{k}\left(R_{M, t}-\right. & \left.C D I_{t}\right)+s_{k} S M B_{t}+h_{k} H M L_{t}+w_{k} W M L_{t}+ \\
& +i_{k} I M L_{t}+\epsilon_{k, t}
\end{aligned}
$$

\section{Results}

\section{I Main results}

Table 1 presents the descriptive statistics for the fundamental indices. Their annualized geometric average returns are higher than those of the IBrX 100 except for the index weighted by shareholders' book equity. However, only the fundamental index calculated with free cash flow, weighted according to the method of Arnott et al. (2005) as shown in Equation 1, presents an excess return in relation to the $\mathrm{IBrX} 100$, with statistical significance at a level of ten percent. The same index was also the only one to present a SR in relation to the CDI with statistical significance at the same level. The annual volatility of the fundamental indices does not stand out from that calculated for the IBrX-100. The ordinal weighting depicted by Equation 2 does not show distinct results and suggests that extreme and negative values of the fundamental indicators do not affect the results obtained with the original weighting of Arnott et al. (2005). The Ibovespa has a negative, but not significant excess return in relation to the $\mathrm{IBrX} 100$. 
Table 1

Descriptive Statistics of the Indices

\begin{tabular}{|c|c|c|c|c|c|c|c|c|c|}
\hline Index & Method & $\begin{array}{c}\text { Annual } \\
\text { Geom. } \\
\text { Return } \\
(\%)\end{array}$ & $\begin{array}{c}\text { Annual } \\
\text { Vol. (\%) }\end{array}$ & SR & $\begin{array}{c}\text { Excess } \\
\text { Annual } \\
\text { Return } \\
(\%)\end{array}$ & $\begin{array}{c}\text { Average } \\
\text { Monthly } \\
\text { Return } \\
(\%) \\
\end{array}$ & $\begin{array}{c}\text { Median } \\
\text { Monthly } \\
\text { Return } \\
(\%)\end{array}$ & $\begin{array}{c}\text { Minimum } \\
\text { Monthly } \\
\text { Return (\%) }\end{array}$ & $\begin{array}{c}\text { Maximum } \\
\text { Monthly } \\
\text { Return (\%) }\end{array}$ \\
\hline \multirow[t]{2}{*}{ Div } & 1 & 16.95 & 20.10 & 0.09 & 0.66 & 1.48 & 1.43 & -19.20 & 15.30 \\
\hline & 2 & 18.58 & 19.60 & 0.11 & 2.21 & 1.59 & 1.34 & -18.74 & 16.09 \\
\hline \multirow[t]{2}{*}{ FCFlow } & 1 & 21.54 & 21.71 & $0.14^{*}$ & $5.73^{*}$ & 1.83 & 2.05 & -15.99 & 15.86 \\
\hline & 2 & 18.19 & 18.65 & 0.10 & 1.59 & 1.55 & 1.14 & -18.51 & 13.93 \\
\hline \multirow[t]{2}{*}{$\mathrm{OpCF}$} & 1 & 17.81 & 22.04 & 0.09 & 2.03 & 1.58 & 1.75 & -21.05 & 15.35 \\
\hline & 2 & 17.41 & 18.88 & 0.09 & 0.86 & 1.49 & 1.18 & -18.30 & 14.29 \\
\hline \multirow[t]{2}{*}{ OpProfit } & 1 & 17.31 & 22.21 & 0.09 & 1.55 & 1.54 & 1.65 & -22.45 & 17.97 \\
\hline & 2 & 17.39 & 19.29 & 0.09 & 0.92 & 1.50 & 1.11 & -18.69 & 15.86 \\
\hline \multirow[t]{2}{*}{ Revenue } & 1 & 17.70 & 22.03 & 0.09 & 1.91 & 1.57 & 1.72 & -22.23 & 17.39 \\
\hline & 2 & 17.78 & 19.65 & 0.10 & 1.40 & 1.53 & 1.33 & -18.97 & 15.10 \\
\hline \multirow[t]{2}{*}{ BV } & 1 & 13.95 & 22.61 & 0.05 & -1.79 & 1.31 & 1.21 & -20.61 & 17.09 \\
\hline & 2 & 15.98 & 19.63 & 0.07 & -0.44 & 1.40 & 1.06 & -19.61 & 14.36 \\
\hline \multirow[t]{2}{*}{ Composite } & 1 & 17.62 & 21.42 & 0.09 & 1.67 & 1.55 & 1.56 & -20.24 & 15.32 \\
\hline & 2 & 17.57 & 19.22 & 0.09 & 1.09 & 1.51 & 1.12 & -18.80 & 14.94 \\
\hline IBrX100 & - & 15.84 & 21.94 & 0.07 & - & 1.43 & 1.56 & -25.11 & 18.34 \\
\hline Ibovespa & - & 12.08 & 22.79 & 0.03 & -3.63 & 1.17 & 1.08 & -24.80 & 15.56 \\
\hline
\end{tabular}

Note. The statistics refer to the 144 monthly returns between June 2003 and May 2015. "Index" is one of the fundamental indices, the IBrX 100, or the Ibovespa. The fundamental indices were weighted according to the fundamental indicators dividends (Div), operating cash flow (OpCF), free cash flow (FCFlow), operating profit (OpProfit), net revenues (Revenue), and book value (BV), all measured in the currency of the country and defined in the Appendix. Method 1 corresponds to the weighting by Equation 1 (Arnott et al, 2005) and Method 2 corresponds to the weighting by Equation 2 (ordinal). The annual geometric return was defined in Equation 4. The annual volatility was defined by Equation 5. The Sharpe Ratio (SR) in relation to the CDI was defined by Equation 6 . The excess return was calculated as the difference between the annualized monthly average return of each index minus the annualized monthly average return from the IBrX 100. Sharpe (1994) shows that the SR multiplied by the square root of the number of observations provides a t-statistic for the significance of the SR in Equation 6. * denotes 10\% significance and ${ }^{* *}$ denotes 5\%, measured by a bilateral t-test.

The composite (or aggregate) fundamental indices shown in Table 1 are portfolios formed by the equal weighting of the fundamental indices calculated according to each one of the fundamental indicators individually. There is no statistical significance for their excess returns in relation to the $\mathrm{IBrX} 100$. It can be concluded that the evidence in Table 1 indicates that the fundamental indexation proposal by Arnott et al. (2005) did not outperform the index weighted by the market value of the free floating stocks that comprise it during the 12 years of the sample. This result also contrasts with those that indicate better performance for fundamental indexation in other countries (Basu \& Forbes, 2014; Mar et al., 2009; Estrada, 2008; Hemminki \& Puttonen, 2008; Hsu \& Campollo, 2006), but is consistent with those that were not conclusive about this (Ferri, 2014; Amenc, Goltz, Lodh, \& Martellini, 2012; Walkshäusl \& Lobe, 2010; Blitz \& Swinkels, 2008).

Table 2 shows the results for the alpha estimated according to the CAPM and fivefactor models according to Equations 7 and 8, respectively. 
Table 2

Analysis of the alpha of the Fundamental Indices

\begin{tabular}{|c|c|c|c|c|c|c|c|c|c|c|c|c|}
\hline \multirow[b]{2}{*}{ Index } & \multirow[b]{2}{*}{$\mathbf{M}$} & \multicolumn{3}{|c|}{ CAPM } & \multicolumn{8}{|c|}{ 5-Factor Model } \\
\hline & & $\begin{array}{c}\alpha \\
(\% \text { pa })\end{array}$ & $\beta$ & $\mathbf{R}^{2}$ & $\begin{array}{c}\alpha \\
(\% \text { pa) }\end{array}$ & $\beta$ & $\mathbf{h}$ & $s$ & $\mathbf{w}$ & i & $\mathbf{R}^{2}$ & $\mathbf{F}$ \\
\hline \multirow{2}{*}{ Div } & 1 & 1.18 & 0.89 & 0.94 & 0.34 & 0.92 & $0.14^{* *}$ & $-0.11^{* *}$ & 0.04 & 0.09 & 0.95 & 533 \\
\hline & 2 & 2.85 & 0.82 & 0.86 & 1.95 & 0.82 & $0.11^{* *}$ & 0.13 & 0.07 & 0.02 & 0.87 & 195 \\
\hline \multirow{2}{*}{ FCFlow } & 1 & $5.43^{* *}$ & 0.91 & 0.83 & 3.50 & 0.93 & $0.15^{* *}$ & -0.02 & $0.11^{* *}$ & 0.02 & 0.84 & 156 \\
\hline & 2 & 2.62 & 0.77 & 0.82 & 1.60 & 0.74 & $0.12^{* *}$ & $0.22^{* *}$ & $0.09^{*}$ & -0.02 & 0.86 & 172 \\
\hline \multirow{2}{*}{ OpCF } & 1 & 1.89 & 0.97 & 0.93 & 1.08 & 0.99 & $0.15^{* *}$ & -0.04 & 0.04 & 0.06 & 0.94 & 473 \\
\hline & 2 & 1.89 & 0.79 & 0.84 & 1.10 & 0.77 & $0.14^{* *}$ & $0.18^{* *}$ & 0.07 & 0.00 & 0.87 & 191 \\
\hline \multirow{2}{*}{ OpProfit } & 1 & 1.37 & 0.99 & 0.96 & 0.57 & 1.01 & $0.13^{* *}$ & -0.02 & $0.05^{*}$ & 0.06 & 0.97 & 893 \\
\hline & 2 & 1.81 & 0.81 & 0.86 & 0.96 & 0.79 & $0.12^{* *}$ & $0.18^{* *}$ & 0.07 & -0.03 & 0.88 & 210 \\
\hline \multirow{2}{*}{ Revenue } & 1 & 1.76 & 0.98 & 0.95 & 1.06 & 0.98 & $0.16^{* *}$ & 0.03 & 0.03 & 0.00 & 0.96 & 671 \\
\hline & 2 & 2.16 & 0.82 & 0.85 & 1.41 & 0.80 & $0.17^{* *}$ & $0.21^{* *}$ & 0.06 & -0.05 & 0.88 & 211 \\
\hline \multirow{2}{*}{ BV } & 1 & -1.37 & 0.97 & 0.89 & -1.28 & 0.98 & $0.27^{* *}$ & -0.01 & -0.03 & 0.03 & 0.91 & 301 \\
\hline & 2 & 0.55 & 0.83 & 0.86 & 0.17 & 0.80 & $0.18^{* *}$ & $0.18^{* *}$ & 0.03 & -0.04 & 0.89 & 232 \\
\hline \multirow{2}{*}{ Composite } & 1 & 1.70 & 0.95 & 0.95 & 0.87 & 0.97 & $0.17^{* *}$ & -0.03 & 0.04 & 0.04 & 0.96 & 678 \\
\hline & 2 & 1.98 & 0.81 & 0.85 & 1.20 & 0.79 & $0.14^{* *}$ & $0.18^{* *}$ & 0.07 & -0.02 & 0.88 & 211 \\
\hline
\end{tabular}

Note. The models were estimated with the 144 monthly returns between June 2003 and May 2015. "Index" is one of the fundamental indices that were weighted according to the fundamental indicators dividends (Div), operating cash flow (OpCF), free cash flow (FCFlow), operating profit (OpProfit), net revenues (Revenue), and book value (BV), all measured in the currency of the country and defined in the Appendix. " $\mathrm{M}$ " is the method of weighting, whose value of 1 corresponds to Equation 1 (Arnott et al, 2005) and 2 corresponds to Equation 2 (ordinal). The CAPM model was estimated according to Equation 7 and the five-factor model as in Equation 8. The alphas were annualized for presentation purposes in the form $(1+\alpha)^{12}-1$. The two models were estimated with robust errors to correct the heteroskedasticity and autocorrelation in the residuals according to the Newey-West method.

* denotes $10 \%$ significance and ** denotes $5 \%$, measured by a bilateral t-test. All betas, in both models, are significant at the level of five percent and all F statistics are significant at the one percent level, thus the asterisks were omitted to save space. No alpha for the five-factor model is significant at the level of 10 percent or less.

Only the fundamental index weighted according to free cash flow in the original form presented statistical significance at the level of five percent for the alpha estimated according to the CAPM. However, this significance disappears with the five-factor model. This result suggests that any merit for fundamental indexation in Brazil is probably due to the effect of value stocks captured by the coefficient of the HML risk factor in Equation 8, which is notably positive and statistically significant for all fundamental indices. In addition, there seems to be a size effect, but to a lesser degree. This evidence is consistent with the criticism of Ferri (2014) and Walkshäusl and Lobe (2010). The results reported, as has already been pointed out, do not support the evidence in favor of fundamental indexation presented by other authors in other countries, but are consistent with the lack of favorable evidence about fundamental indices in Brazil presented in Walkshäusl and Lobe (2010).

\subsection{Comparison with the stock funds}

Table 3 presents a summary of the comparative analysis of the fundamental index, built according to free cash flow in the original form, with the 42 selected stock funds. This comparison is carried out because this fundamental index was the only one to present statistically significant performance in the previous tests. 
The stock funds showed an annualized volatility similar to the fundamental index, but always at a higher level. Santiago and Leal (2015) affirm that stock funds usually have a lower volatility than equally weighted portfolios, but this was not the case in relation to fundamental indexation. On the other hand, the fundamental index based on free cash flow with the weighting suggested by Arnott et al. (2005) showed an annualized return greater than the best stock fund in the sample.
The groups of stock funds listed in Table 3 do not present positive and statistically significant excess returns and alphas. It is worth highlighting that the stock funds selected are surviving funds because they would have to be in operation throughout the entire sample period. It would not be surprising if surviving stock funds presented outstanding performance, but this was not the case for the majority of the stock funds selected, which are open to investors in general.

Table 3

\section{Fundamental Index and Stock Funds}

\begin{tabular}{|c|c|c|c|c|c|c|c|}
\hline $\begin{array}{l}\text { Fundamental Index or } \\
\text { stock funds or IBrX } 100\end{array}$ & $\begin{array}{l}\text { Annual } \\
\text { Return } \\
\text { (\% p.a.) }\end{array}$ & $\begin{array}{c}\text { Annual } \\
\text { Volatility (\%) }\end{array}$ & SR & $\begin{array}{l}\text { Excess Return } \\
\quad(\% \text { p.a. })\end{array}$ & $\begin{array}{l}\text { Alpha } \\
\text { (\% p.a.) }\end{array}$ & Beta & $\mathbf{R}^{2}$ \\
\hline FCFlow & 21.54 & 21.71 & $0.14^{*}$ & $5.73^{*}$ & $5.43^{* *}$ & 0.91 & 0.83 \\
\hline Best stock fund & 19.66 & 23.82 & 0.11 & 4.44 & 3.76 & 1.01 & 0.86 \\
\hline 5 Best stock funds & 18.55 & 22.31 & 0.10 & 2.86 & 2.51 & 0.99 & 0.95 \\
\hline 10 Best stock funds & 17.42 & 22.26 & 0.09 & 1.69 & 1.51 & 0.99 & 0.95 \\
\hline 15 Best stock funds & 16.29 & 22.16 & 0.08 & 0.51 & 0.51 & 0.99 & 0.96 \\
\hline 20 Best stock funds & 15.49 & 21.98 & 0.07 & -0.36 & -0.19 & 0.98 & 0.95 \\
\hline 25 Best stock funds & 14.68 & 21.94 & 0.06 & -1.20 & -0.91 & 0.98 & 0.96 \\
\hline 30 Best stock funds & 13.71 & 21.95 & 0.05 & -2.18 & -1.76 & 0.98 & 0.96 \\
\hline 35 Best stock funds & 12.86 & 21.91 & 0.04 & $-3.06^{* *}$ & $-2.50^{* *}$ & 0.98 & 0.96 \\
\hline All stock funds & 11.76 & 21.94 & 0.02 & $-4.16^{* *}$ & $-3.45^{* *}$ & 0.98 & 0.96 \\
\hline IBrX 100 & 15.84 & 21.94 & 0.07 & - & - & - & - \\
\hline
\end{tabular}

Note. The analysis refers to the 144 months between June 2003 and May 2015. The annual return is the geometric mean of the annualized monthly returns according to Equation 4. The annual volatility is the annualized monthly standard deviation as depicted by Equation 5. The SR, or Sharpe Ratio, was calculated according to Equation 6. Equal weights were used for each stock fund in the groups of stock funds. The excess return is the annualized monthly average return of the stock fund or fundamental index minus the annualized monthly average return of the IBrX 100. The t-test performed was two-tailed for the significance of the difference between these two averages. The alpha presented refers to the one estimated by CAPM, as depicted in Equation 7. The Jensen's alpha (1968) is annualized in the form $(1+\alpha)^{12}-1$ for presentation purposes. The best stock funds were classified according to their SR.

* and ${ }^{* *}$ denote statistical significance at the level of ten and five percent, respectively. All betas are significant and, therefore, this notation has been omitted for them.

The results in Table 3 indicate that the fundamental index weighted by free cash flow in the original form of Arnott et al. (2005) presented the best performance, even when compared to the best surviving stock fund in the period analyzed. This is portrayed by means of the higher return, lower volatility, higher alpha, and lower correlation with the IBrX 100. Of course, this result should be interpreted considering the appropriate limitations arising from the sample. It can also be noted that the results for the alphas of the stock funds are consistent with those presented by other Brazilian authors that highlight that less than five percent of the stock funds have positive and statistically significant alphas (Castro \& Minardi, 2009; Laes \& Silva, 2014).

Table 4 ascertains whether there is different behavior between times of stock market highs 
and stock market lows. The decision was made to present the results for the composite indices because they represent an equally weighted portfolio of all fundamental indices analyzed here. The table shows the proportion of times that each composite fundamental index or stock fund outperformed the $\mathrm{IBrX} 100$ in each range of performance for this index in the sample period. This proportion increases in the lower IBrX 100 performance bands, and is high in negative performance ranges. This effect is even more noticeable with the fundamental indices weighted in the ordinal form (Equation 2). These results are in line with those found by Basu and Forbes (2014) and indicate that fundamental indexation can offer better performance in low market periods. This defensive characteristic of fundamental indexation supports, once again, the conjecture that it is nothing more than a value stocks strategy that would be better in times of lower growth in the stock market (Ferri, 2014). The results for the actively managed stock funds were not so clear, possibly because they pursue varied investment strategies and some of them have characteristics closer to growth strategies and others closer to value stocks.

Table 4

Monthly comparison of fundamental indices and stock funds with the IBrX 100

\begin{tabular}{|c|c|c|c|c|c|}
\hline $\begin{array}{l}\text { Return Range of } \\
\text { IBrX } 100\end{array}$ & $\begin{array}{c}\text { No. months of IBrX } \\
100 \text { in the return } \\
\text { range }\end{array}$ & $\begin{array}{l}\text { Composite } \\
\text { Fund. Index } \\
\text { (1) }\end{array}$ & $\begin{array}{l}\text { Composite } \\
\text { Fund. Index } \\
\text { (2) }\end{array}$ & $\begin{array}{l}\text { Best Stock } \\
\text { Fund }\end{array}$ & All Stock Funds \\
\hline$>10 \%$ & 10 & $20 \%$ & $20 \%$ & $50 \%$ & $40 \%$ \\
\hline 5 to $10 \%$ & 32 & $47 \%$ & $25 \%$ & $53 \%$ & $44 \%$ \\
\hline 0 to $5 \%$ & 45 & $56 \%$ & $44 \%$ & $58 \%$ & $29 \%$ \\
\hline$-5 \%$ to $0 \%$ & 38 & $66 \%$ & $76 \%$ & $63 \%$ & $47 \%$ \\
\hline$-10 \%$ to $-5 \%$ & 15 & $53 \%$ & $67 \%$ & $60 \%$ & $33 \%$ \\
\hline$<-10 \%$ & 4 & $50 \%$ & $100 \%$ & $75 \%$ & $75 \%$ \\
\hline
\end{tabular}

Note. The percentages indicate the proportion of months in each range of returns that a composite fundamental index or stock fund outperformed the IBrX 100. "Composite Fund. Index (1)" is the composite fundamental index weighted according to the method of Arnott et al. (2005), as shown in Equation 1. "Composite Fund. Index (2)" is the composite fundamental index weighted according to the ordinal method, as shown in Equation 2. The sample of stock funds consists of 42 funds surviving during the entire sample period and intended for investors in general.

\subsection{Additional tests}

The tests performed in Tables 1 and 2 were repeated for fundamental indices weighted based on the average of the last two and three years for each fundamental indicator. The evidence was similar, and the results are not reported, but are available from the authors. Arnott et al. (2005) suggested the use of averages of the fundamental indicators as an alternative.

Transaction costs can also affect some results and therefore were an object of analysis in this study. Santiago and Leal (2015) estimated the transaction costs for $1 / \mathrm{N}$ portfolios rebalanced once a year at around 400 basis points per year, equivalent to 33 basis points per month. These costs include the income tax rate of 15 percent, brokerage, services tax, charges, and custody fee. In this analysis, therefore, the gross monthly return of the fundamental indices was reduced by the total transaction cost, estimated at 33 basis points per month.

The IBrX 100 is an index and, of course, there is no transaction costs embedded in its calculation. For the purposes of comparison with the net returns of the fundamental indices estimated in the form described above, an investment in the IBrX 100 was subjected to a management fee of 0.5 percent a year and to the rate of 15 percent for income tax, which would 
reflect an IBrX 100 indexed stock fund. This leads to a monthly average transaction cost of 26 basis points (15 percent times the monthly average return of the $\operatorname{IBrX} 100$ in the period analyzed of 1.43 percent plus the management fee of $0.5 / 12$ percent per month). In the case of stock funds, only the 15 percent rate of income tax was deducted from monthly returns because they are already net of management fees. Mathematically, the monthly net return of a fundamental index or the IBrX 100 was calculated as being equal to the monthly gross return minus 0.33 or 0.26 percentage points, respectively. As for the stock funds, their monthly gross return was multiplied by one minus the 15 percent rate of income tax.

The mean tests of Table 1 and the estimates of the CAPM alphas from Table 2 were repeated for the net returns. Any statistical significance before transaction costs disappeared for both the differences of means and for the alphas. Although the performance of the fundamental indices continues to be better than that of the stock funds, the difference between net monthly average returns of the fundamental index based on free cash flow and that of the best stock fund is not significant. In general, the little significance observed in some tests does not persist when transaction costs are considered. Therefore, there was no need to apply the five-factor model to the net returns. Just to illustrate, the annual geometric average return of the fundamental index weighted by net cash flow in the original form was $21.54 \%$ before transaction costs and $17.54 \%$ after them. The same measurement for the best stock fund went from $19.66 \%$ to $16.71 \%$. These results are not reported in this article, but are available from the authors.

\section{Conclusions}

This article analyzed portfolios composed according to fundamental indexation in Brazil between June 2003 and May 2015 for companies present in the theoretical portfolio of the IBrX 100. These portfolios, or fundamental indices, are weighted by weights calculated on the basis of selected fundamental indicators. Arnott et al. (2005) proposed the fundamental indicators used to build them and these include revenue, operating profit, dividends, book value, operating cash flow, and free cash flow, all measured in Brazilian currency. The weight of each stock in a fundamental index is the value of its fundamental indicator divided by the sum of the same indicator in all the companies that make up the fundamental index. An ordinal weighting was also employed to assess the impact of extreme values from the fundamental indicators on the weights.

The performance of the fundamental indices was compared to that of the IBrX 100 and a sample of 42 stock funds surviving during the entire sample period and intended for investors in general. The results suggest that there is no outperformance of fundamental indices in relation to the $\operatorname{IBrX} 100$ and to stock funds. Only the fundamental index built according to free cash flow showed statistical significance for the Jensen's alpha and the average return, but this disappears when transaction costs are included or when estimating the alpha with a version of the Fama and French (1993) model extended to five risk factors. It was not possible to observe any significant result for the ordinal weighting. Finally, it should be noted that the fundamental indices achieved better performance than the IBrX 100 more frequently in times of a bear stock market. This defensive behavior and the HML factor coefficient of the five-factor model is consistent with that of value stocks and lends support to the affirmation of Ferri (2014) that these indices end up behaving according to the factors of Fama and French (1993), being priced by this model and, therefore, not generating abnormal returns when adjusted to their risk factors. The lack of results clearly favoring fundamental indexation in Brazil is consistent with the fact that there are no funds that employ it in the country. It is clear that the results reported were obtained during a relatively short period of time and may even be contingent on the period analyzed. 
As suggestions for future studies, more stocks could be included in the sample in addition to the components of the $\operatorname{IBrX} 100$, and the number of stocks in each fundamental index could be limited to make implementation easier for a less sophisticated investor. Another suggestion would be to consider samples segregated according to the four different trading segments of the BM\&FBovespa, which differ according to corporate governance and transparency requirements, or ones that are present in the Corporate Sustainability Index (ISE), in order to verify whether this differentiation according to the greater commitment to best corporate governance, social responsibility, and corporate sustainability practices is a relevant factor for building fundamental indices in the country.

\section{References}

Amenc, N., Goltz, F., Lodh, A., \& Martellini, L. (2012). Diversifying the diversifiers and tracking the tracking error: Outperforming cap-weighted indices with limited risk of underperformance. The Journal of Portfolio Management, 38(3), 72-88. doi:10.3905/jpm.2012.38.3.072

Arnott, R., \& Hsu, J. (2008). Noise, CAPM and the size and value effects. Journal of Investment Management, 6(1), 1-11. doi:10.2139/ ssrn. 928167

Arnott, R., Hsu, J., \& Moore, P. (2005). Fundamental indexation. Financial Analysts Journal, 61(2), 83-99. doi:10.2469/faj.v61. n2.2718

Arnott, R., \& West, J. (2006). Fundamental indexes: current and future applications. ETFs and Indexing, 2006(1), 111-121. Retrieved from https://goo.gl/CYy66G

Associação Brasileira das Entidades dos Mercados Financeiro e de Capitais. (2016, February). Consolidado Histórico de Fundos de Investimento. Retrieved from https://goo.gl/91S32V

Basu, A. K., \& Forbes, B. (2014). Does fundamental indexation lead to better riskadjusted returns? New evidence from Australian
Securities Exchange. Accounting and Finance, 54(3), 699-728. doi:10.1111/acfi.12016

Blitz, D., \& Swinkels, L. (2008). Fundamental indexation: An active value strategy in disguise. Journal of Asset Management, 9(4), 264-269. doi:10.1057/jam.2008.23

BM\&FBOVESPA. (2015a, April). Metodologia do Indice Brasil 100 (IBrX 100). Retrieved from https://goo.gl/HyEZFF.

BM\&FBOVESPA. (2015b, April). Metodologia do Indice Bovespa. Retrieved from https://goo. $\mathrm{gl} / \mathrm{vQyeu}$.

Carhart, M. (1997). On persistence in mutual fund performance. Journal of Finance, 52(1), 5782. doi:10.1111/j.1540-6261.1997.tb03808.x

Castro, B. R., \& Minardi, A. M. A. F. (2009). Comparação do desempenho dos fundos de açôes ativos e passivos. Revista Brasileira de Finanças, 7(2), 143-161. Retrieved from http:// bibliotecadigital.fgv.br/ojs/index.php/rbfin/ article/viewFile/1310/918

Chen, C., Chen, R., \& Basset, G. W. (2007). Fundamental indexation via smoothed cap weights. Journal of Banking \& Finance, 31(11), 3486-3502. doi:10.1016/j.jbankfin.2007.04.010

Dana, S. (2015, July 20). Estudo mostra que a renda fixa ganha da Bolsa no longo prazo no país. Folha de São Paulo. Retrieved from https://goo.gl/ qOJiEl

Estrada, J. (2008). Fundamental indexation and international diversification. The Journal of Portfolio Management, 34(3), 93-109. doi:10.2139/ssrn.949162

Fama, E. F., \& French, K. R. (1993). Common risk factors in the returns on stocks and bonds. Journal of Financial Economics, 33(1), 3-56. doi:10.1016/0304-405X(93)90023-5

Ferri, R. (2014). Smart beta is not smart for everyone. Journal of Financial Planning, 27(3), 24. 
Graham, J. (2012). Comment on the theoretical and empirical evidence of fundamental indexing. Journal of Investment Management, 10(1), 90-98.

Haugen, R. A., \& Baker, N. L. (1991). The efficient market inefficiency of capitalizationweighted stock portfolios. The Journal of Portfolio Management, 17(3), 35-40. doi:10.3905/ jpm.1991.409335

Hemminki, J., \& Puttonen, V. (2008). Fundamental indexation in Europe. Journal of Asset Management, 8(6), 401-405. doi:10.1007/978-3319-30794-7_14

Hsu, J. C. (2006). Cap-weighted portfolios are sub-optimal portfolios. Journal of Investment Management, 4(3), 1-10. doi:10.2139/ssrn.647001

Hsu, J. C., \& Campollo, C. (2006). New frontiers in index investing: An examination of fundamental indexation. Journal of Indexes, 32-38. Retrieved from https:/goo.gl/JR1kTj

Investment Company Institute (2016). 2016 Investment Company Factbook. Retrieved from http://www.icifactbook.org/ch2/16_fb_ch2

Jensen, M. (1968). The performance of mutual funds in the period 1945-1964. Journal of Finance 23(2), 389-416. doi:10.1111/j.1540-6261.1968. tb00815.x

Kaplan, P. D. (2008). Why fundamental indexation might-or might not-work. Financial Analysts Journal, 64(1), 32-39. doi:10.2469/faj. v64.n 1.5

Keene, M. A., \& Peterson, D. R. (2007). The importance of liquidity as a factor in asset pricing. Journal of Financial Research, 30(1), 91-109. doi:10.1111/j.1475-6803.2007.00204.x

Laes, M. A., \& Silva, M. E. (2014). Performance of mutual equity funds in Brazil - A bootstrap analysis. EconomiA, 15(3), 294-306. doi: https:// doi.org/10.1016/j.econ.2014.08.002

Ledoit, O., \& Wolf, M. (2008). Robust performance hypothesis testing with the Sharpe ratio. Journal of Empirical Finance, 15(5), 850859. doi:10.1016/j.jempfin.2008.03.002
Machado, M. A. V., \& Medeiros, O. R. (2011). Modelos de precificação de ativos e o efeito liquidez: evidências empíricas no mercado acionário brasileiro. Revista Brasileira de Finanças, 9(3), 383-412. Retrieved from https://goo. $\mathrm{gl} / 2 \mathrm{jrk} 83$

Mar, J., Bird, R., Casavecchia, L., \& Yeung, D. (2009). Fundamental indexation: An Australian investigation. Australian Journal of Management, 34(1), 1-20. doi:10.1177/031289620903400102

Markowitz, H. (2005). Market efficiency: A theoretical distinction and so what? Financial Analysts Journal, 61(5), 17-30. doi:10.2469/faj. v61.n5.2752

Mendonça, H. F., Galvão, D. J. C., \& Loures, R. F. V. (2011). Exuberância e risco do mercado financeiro: herança do Governo Lula. Revista Economia \& Tecnologia, 7, 63-68. https://doi. org/10.5380/ret.v7i0.26883

Perold, A. F. (2007). Fundamentally flawed indexing. Financial Analysts Journal, 63(6), 31-37. doi:10.2469/faj.v63.n6.4924

Santiago, D. C., \& Leal, R. P. C. (2015). Carteiras igualmente ponderadas com poucas açóes e o pequeno investidor. Revista de Administração Contemporânea, 19(5), 544-564. doi:10.1590/1982-7849rac20151794

Sharpe, W. F. (1994). The Sharpe Ratio. Journal of Portfolio Management, 21(1), 49-58. doi:10.3905/ jpm.1994.409501

Siegel, J. (2015). Investindo em açôes no longo prazo (5a ed.). Porto Alegre: Bookman.

Treynor, J. (2005). Why market-valuationindifferent indexing works. Financial Analysts Journal, 61(5), 65-69. doi:10.2469/faj.v61. $\mathrm{n} 5.2757$

Walkshäusl, C., \& Lobe, S. (2010). Fundamental indexing around the world. Review of Financial Economics, 19(3), 117-127. doi:10.1016/j. rfe.2010.02.001 


\section{APPENDIX}

Definition of fundamental indicators (with respective Bloomberg codes)

\begin{tabular}{|l|l|}
\hline Variable & Definition (Bloomberg Code) \\
\hline Div & $\begin{array}{l}\text { Dividends. Includes dividends and interest on capital actually paid in cash, including common shares of the parent } \\
\text { company and preferred shares of all consolidated companies (CF_DVD_PAID). }\end{array}$ \\
\hline OpProfit & $\begin{array}{l}\text { Operational profit. Net sales plus other operating profit minus cost of goods sold minus other operating losses (IS_ } \\
\text { OPER_INC). }\end{array}$ \\
\hline FCFlow & $\begin{array}{l}\text { Free cash flow. Cash flow from operating activities minus total capital expenditure. Capital expenditure is the amount } \\
\text { that the company spent on the purchase of tangible fixed assets (CF_FREE_CASH_FLOW) }\end{array}$ \\
\hline OpCF & $\begin{array}{l}\text { Operating cash flow. The total value of the cash flow generated by the operations of a company calculated as net profit } \\
\text { plus depreciation and amortization plus other adjustments not related to cash flow plus changes in working capital } \\
\text { (CF_CASH_FROM_OPER). }\end{array}$ \\
\hline Revenue & $\begin{array}{l}\text { Net revenue. Total operating income, minus various adjustments on gross sales such as returns, provisions, taxes } \\
\text { withheld, insurance charges, sales taxes, and value added taxes (SALES_REV_TURN). }\end{array}$ \\
\hline BV & Book value of equity. The total of the stock capital plus retained earnings (TOT_COMMON_EQY). \\
\hline
\end{tabular}

\section{Notes:}

1 This article partially derives from the doctoral dissertation of Raphael Moses Roquete titled «Indexaçáo fundamentalista aplicada ao Brasil», Federal University of Rio de Janeiro, The Coppead Graduate School of Business, Rio de Janeiro, 2017. 


\section{About the Authors:}

1. Raphael Moses Roquete, D. Sc. in Business Administration, Federal University of Rio de Janeiro, The Coppead Graduate School of Business. E-mail: raphael.moses@coppead.ufrj.br

\section{ORCID}

(iD) 0000-0001-5554-0379

2. Ricardo Pereira Câmara Leal, D. Sc. in Business Administration, Federal University of Rio de Janeiro, The Coppead Graduate School of Business. E-mail: ricardoleal@coppead.ufrj.br

ORCID

(iD) 0000-0002-4516-9788

3. Carlos Heitor Campani, Ph. D. in Finance, École des Hautes Études Commerciales du Nord, EDHEC Business School. E-mail: carlos.heitor@coppead.ufrj.br

ORCID

(iD) 0000-0003-1896-7837

\section{Contribution of each author:}

\begin{tabular}{|c|c|c|c|}
\hline Contribution & $\begin{array}{c}\text { Raphael Moses } \\
\text { Roquete }\end{array}$ & $\begin{array}{c}\text { Ricardo Pereira } \\
\text { Câmara Leal }\end{array}$ & $\begin{array}{c}\text { Carlos Heitor } \\
\text { Campani }\end{array}$ \\
\hline 1. Definition of research problem & $\sqrt{ }$ & $\sqrt{ }$ & \\
\hline 2. Development of hypotheses or research questions (empirical studies) & $\sqrt{ }$ & $\sqrt{ }$ & \\
\hline \multicolumn{4}{|l|}{ 3. Development of theoretical propositions (theoretical work) } \\
\hline 4. Theoretical foundation/Literature review & $\sqrt{ }$ & $\sqrt{ }$ & \\
\hline 5. Definition of methodological procedures & $\sqrt{ }$ & $\sqrt{ }$ & $\sqrt{ }$ \\
\hline 6. Data collection & $\sqrt{ }$ & & \\
\hline 7. Statistical analysis & $\sqrt{ }$ & & \\
\hline 8. Analysis and interpretation of data & $\sqrt{ }$ & $\sqrt{ }$ & $\sqrt{ }$ \\
\hline 9. Critical revision of the manuscript & $\sqrt{ }$ & $\sqrt{ }$ & $\sqrt{ }$ \\
\hline 10. Manuscript writing & $\sqrt{ }$ & $\sqrt{ }$ & \\
\hline
\end{tabular}

